\title{
Energy Recovery Equipment and Control Strategies in Various Climate Regions
}

\author{
Rand Talib, Alexander Rodrigues, Nabil Nassif*
}

Department of Civil and Architectural Engineering and Construction Management, University of Cincinnati, Cincinnati, OH 45221, USA.

\begin{tabular}{l} 
A R T I C L E I N F O \\
\hline Article history: \\
Received: 27 March, 2020 \\
Accepted: 26 May, 2020 \\
Online: 06 July, 2020 \\
\hline Keywords: \\
Building energy consumption \\
Energy recovery systems \\
Physics based simulation \\
Bin method energy model \\
Climate zone design optimizations
\end{tabular}

\section{Introduction}

The building stock is the largest consumer of energy in the United States, estimated to consume 40.3 quadrillion Btus or about $39 \%$ of total U.S energy consumption, making the reduction of energy consumed in buildings of paramount importance [1]. The building's heating, cooling, and ventilation systems are the single largest energy consumers of any other system, totaling about 13.5 quadrillion Btus or $35 \%$ of total energy use [2]. With humans spending $90 \%$ of their time indoors and the increased reliance on buildings in everyday life, creating an indoor environment that is healthy, comfortable, and productive becomes critical [3]. ASHRAE Standard 62.1-2016 addresses the ventilation requirements to ensure these indoor spaces are comfortable to the occupants [4]. Hence, the area of overlap between human comfort and energy efficiency has warranted further research and enhancement.

With the arising issues of global warming and the cost of energy the need for more efficient building systems became more crucial [5]. Thus, system designers and engineers always exploring new ways of implementing new technologies for a better design and operation of HVAC systems. One of the methods is implementing the heat/energy recovery devices [6]. An air to air energy recovery heat exchanger includes but is not limited to, heat recovery ventilators and energy recovery ventilators. Those devices are placed in the units where the exchange between the outdoor air and return air is happening. The exhaust air of the

*Nabil Nassif, Email: nassifnl@ucmail.uc.edu building passes through one side of the exchanger while the outside makeup air passes through the other side of the exchanger. In the cooling season the return cooled indoor air is used to precool the outside incoming air. While, this process is reversed during the heating season when the exchanger is using the exhaust warm air to preheat the outside incoming air. However, heat exchanger might transfer sensible heat only or sensible and latent heat depending on the use. Various types of heat exchangers are available nowadays with efficiencies ranging from $55 \%$ to almost $80 \%$ [7]. Moreover, various types of air to air energy recovery devices are available such as, the heat pipe exchanger, the open and closed runaround systems, the thermal wheel, and the plate exchanger [8].

Therefore, system designers are more frequently considering the use of air to air energy recovery systems to reduce the amount of energy HVAC systems consume. Local building jurisdictions and national design standards have also evolved to require energy recovery in more applications. Although established standards indicate when energy recovery systems are required and their minimum technical requirements, little guidance is available in the optimal selection of the type of system, and the control strategies that will produce maximum energy reduction [9]. Moreover, with the many benefits that comes with using a heat exchanger device some disadvantages may occur. One of the problems is the frosting inside the exchangers especially when used in cold regions as Canada and Northern Europe. This issue might result in decreasing the performance of the exchangers. Therefore, it should be taken into consideration when selecting the exchangers [10]. However, 


\section{R. Talib et al. /Advances in Science, Technology and Engineering Systems Journal Vol. 5, No. 4, 47-53 (2020)}

with the growing industry and the new technologies that are being discovered every and the many heat recovery devices that are available nowadays. Many engineers wonder about the type of energy recovery device that should be used, what size, what type, what location and when? Also, what is the algorithm of integrating it into the HVAC system? What is the required maintenance? What is the payback period of that installation? And most importantly what can I expect the performance to be like? Since the answer might require an exact and detailed calculations. Many answers were discussed in few articles, but the search is still ongoing.

Previous studies have compared between multiple types of heat recovery systems. However, the studies have been done on the same zone, same AHU, and or same building but different AHU. On that note, a study was conducted on southern Illinois university laboratory building comparing between two types of energy recovery systems on two different zones. Compare to a $100 \%$ fresh air base case. It was found that the glycol runaround loop heat recovery system gave an annual energy saving of $17.8 \%$. while, implementing a return air heat recovery system resulted in a $17.9 \%$ savings of the annual energy use [11]. The downside of those studies is that the comparison was done based on the same climate zone or location. For better estimation of the energy savings of implementing the energy recovery systems, different climate zones should be assessed. Since climate conditions of each location has tremendous effect on the performance of the energy recovery system.

This paper's objective is to study the differences in energy consumption among various energy recovery systems located in various climate zones and provide useful guidance in selecting an efficient system that yields maximum energy savings. The proposed modelling technique is tested by performing experiments on a 3-ton DX split-system heat pump. The experiment is prepared utilizing a specially integrated unit in a controlled setting. The heat pump runs under various outside conditions and in heating and cooling modes. All the various types of energy recovery systems will be implemented in all the selected zones. And, the results will be fully discussed.

\section{Energy Recovery Systems}

The concept of air-to-air energy recovery is to use the energy of the exhaust air stream to precondition the ventilation air being brought in from outside. According to ASHRAE 90.1-2016, systems with good potential for energy recovery, dictated by location, operational hours, flow rates, and outside air percentages, shall implement energy recovery systems with an Energy Recovery Effectiveness (ERE) of $\geqslant 50 \%$.

$$
E R E=\frac{m_{o a}}{\dot{m}_{o a}} * \frac{\left(h_{o}-h_{o \prime}\right)}{\left(h_{o}-h_{e a}\right)}
$$

Heat recovery installation can considerably reduce the total energy consumption of the system as well as the capital cost of the secondary heating and cooling equipment. Air to air heat recovery is essential for HVAC design and operation for multiple reasons like:

\section{1) Reducing the peak energy rates as well as operation cost}

2) Allows for a higher ventilation rates that will help in creating a better indoor air quality rates at a minimum auxiliary energy consumption that will help not in only provide a better environment for the inhabitants but will also reduce the cost of operation [12].
Also, a study examined a CFD model implemented to optimize the energy performance while maximizing the indoor air quality of a building that is equipped with a heat recovery wheel. It was found that $43 \%$ of savings in the annual energy consumption was achieved when using the energy recovery wheel comparing to a $100 \%$ fresh air case (no energy recovery wheel). While maintain an acceptable IAQ level without violating the ASHRAE standard for acceptable $\mathrm{CO} 2$ concentration in breathing spaces [13].

Depending on various project factors, a design engineer may choose to implement different forms of air-to-air energy recovery systems for various reasons. For the scope of this study, the performance of a coil loop, heat pipe, sensible wheel, and total energy wheel will be evaluated against and optimized for various locations with various weather conditions.

Coil loops consist of two hydronic coils with a glycol solution as the energy transfer medium. Sensible heat is transferred between the exhaust air and the outside air, cooling the outside air in the summer and heating it in the winter. Coil loops have the advantage of not having any cross contamination between exhaust air and outside air, and not requiring air intakes and exhaust locations to be located near one another [14].

Heat pipes are similar to coil loops as they both recover only sensible heat through hydronic piping. Heat pipes however require the air streams to be side by side. The coils are continuous from one air stream to the other and are filled with refrigerant. The refrigerant is pressurized, and when exposed to warm air on one side and cold air on the other, convection is induced, allowing the system to operate without a pump. Though slightly more efficient than a coil loop, the continuous piping between air streams makes it hard to completely prevent cross contamination [14].

Sensible wheels are rotating cylindrical wheels positioned in the duct allowing air to pass through it. In the duct, the wheel is divided into two equal sections, allowing for both the outside air and the exhaust air to pass through. As the wheel rotates, it indirectly exchanges sensible heat between the outside air and the exhaust air streams. In winter, it exchanges heat from the exhaust air to the outside air and in summer, it exchanges heat from the outside air to the exhaust air. Though the heat transfer is indirect, there are areas of carry over near the divide of the wheel, where cross contamination of the air streams is possible. In order to make up for the cross leakage of airstreams, additional outside air is brought in based on the outside air correction factor [15].

Total energy wheels are similar to sensible wheels in their installation and rotating nature, however total energy wheels have the added benefit of also transferring latent energy between the air streams. The majority of wheels are made with a honeycomb type aluminum matrix coated with desiccant. This desiccant allows the wheel to run at lower outdoor temperatures in the winter without ice buildup. Two main media types used in wheels are synthetic fiber and polymers, both with similar effectiveness; they do, however, vary in depth, maintenance, and weight. In order to rotate the wheel a motor ranging from $1 / 3$ to $5 \mathrm{HP}$ is required depending on the media type [15].

In all these forms of energy recovery systems, there is additional fan power needed to overcome the added pressure drop caused by the added recovery systems. The fan energy consumed by a system is a function of the volumetric flow rate, differential pressure, and the efficiency of the fan. Listed in Table 1 is a breakdown of the various energy recovery systems in the study, and their associated technical information. 
Table 1: Energy recovery systems and technical information

\begin{tabular}{|c|c|c|c|c|}
\hline System & $\begin{array}{c}\text { Transfer } \\
\text { Medium }\end{array}$ & $\begin{array}{c}\text { Sensible } \\
\text { Eff. }\end{array}$ & $\begin{array}{c}\text { Latent } \\
\text { Eff. }\end{array}$ & $\begin{array}{c}\text { Fan Pressure } \\
\text { Drop }\end{array}$ \\
\hline $\begin{array}{c}\text { Coil } \\
\text { Loop }\end{array}$ & $\begin{array}{c}30 \% \\
\text { glycol }\end{array}$ & $45 \%$ & -- & 0.5 inwg \\
\hline $\begin{array}{c}\text { Heat } \\
\text { Pipe }\end{array}$ & R134A & $50 \%$ & -- & 0.7 inwg \\
\hline $\begin{array}{c}\text { Sensible } \\
\text { Wheel }\end{array}$ & Wheel & $70 \%$ & -- & 0.8 inwg \\
\hline $\begin{array}{c}\text { Total } \\
\text { Energy } \\
\text { Wheel }\end{array}$ & Wheel & $70 \%$ & $70 \%$ & 1 inwg \\
\hline
\end{tabular}

\section{Building Description}

For the model, a 72,000 square-foot office building was assumed. Using ASHRAE Standard 62.1-2016, the minimum outside air flow rate was computed to be 7,000 CFM with 6,300 CFM of exhaust air. The building was assumed to be occupied on business days during business hours, $8 \mathrm{am}-4 \mathrm{pm}$, with 1,000 people in the space. Building was modelled using eQuest software [16].

Table 2: Assumed building characteristics

\begin{tabular}{|c|c|}
\hline Building Assumption & Value \\
\hline Building Type & Office Space \\
\hline Building Size & 72,000 square-feet \\
\hline OA to Building & 7,000 CFM \\
\hline EA out of Building & 6,300 CFM \\
\hline Building Schedule & $\begin{array}{c}\text { Operational during business } \\
\text { days; 8am }-4 \mathrm{pm} ; 1000 \\
\text { building occupants }\end{array}$ \\
\hline
\end{tabular}

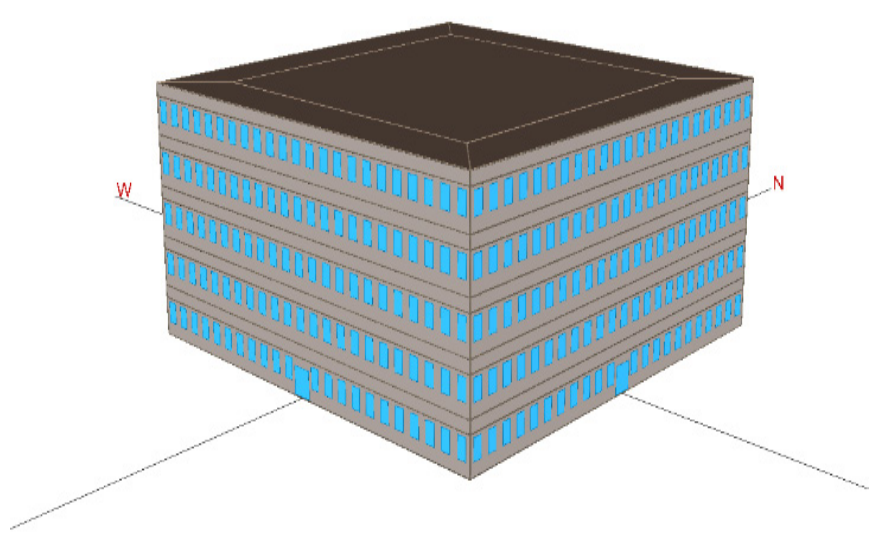

Figure 1: Building model in eQuest [16].

The model's intended goal is to replicate the mechanical conditioning process that occurs in the building's air handling units. In order to accomplish this, the process was broken down into four major steps. The stage points mentioned in the modelling section are illustrated in Figure 2 for ease of understanding the whole aspect.

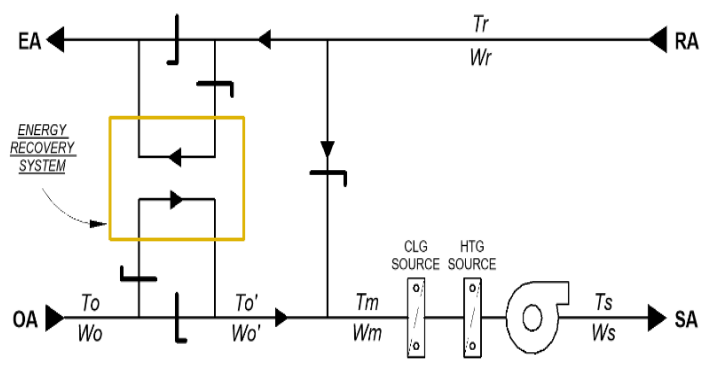

Figure 2: System schematic diagram with noted air stage points

\section{Modeling}

To study the building energy consumption with various energy recovery systems in different climate zones, a bin energy model was created [17]. Bin energy models refer to a procedure where annual weather data is sorted into discrete bins of weather conditions. As this study focuses on the comparison of energy consumption and associated energy reduction among different energy recovery systems in various locations, a bin model was deemed appropriate. Each bin contains the average number of hours of occurrence for a specific dry bulb temperature set during a year. The 8,760 hours in the year are divided into three scheduled categories based on occurrence: $12 \mathrm{am}-8 \mathrm{am}, 8 \mathrm{am}-4 \mathrm{pm}$, and $4 \mathrm{pm}-$ 12am. Along with each dry bulb temperature bin, the mean coincident wet bulb temperature is given. For this model, weather data was acquired from the National Climatic Data Centre [18]. The locations being tested are displayed in Table 3 .

Table 3: Modeled locations and ASHRAE Climate Zone

\begin{tabular}{|c|c|}
\hline Location & ASHRAE Climate Zones \\
\hline Cincinnati, Ohio & $4 \mathrm{~A}$ \\
\hline Fargo, North Dakota & $7 \mathrm{~A}$ \\
\hline Miami, Florida & $1 \mathrm{~A}$ \\
\hline San Francisco, California & $3 \mathrm{C}$ \\
\hline Phoenix, Arizona & $2 \mathrm{~B}$ \\
\hline
\end{tabular}

Moreover, the specification of each location as the environmental parameters and the annual heating, cooling and dehumidification design conditions are shown in table 4. Those data are given to illustrate the weather tendency in each location. The climate design information is obtained from the ASHRAE handbook of fundamentals [19]

Table 4: Climate design information for the modeled locations (Latitude and longitude: \% elevation: $\mathrm{ft} / \mathrm{DB}:{ }^{\circ} \mathrm{F} / \mathrm{HDD}$ and $\mathrm{CDD}$ 65: Annual heating and cooling degree-days, base $65^{\circ} \mathrm{F},{ }^{\circ} \mathrm{F}$-day)

\begin{tabular}{|l|l|l|l|l|l|}
\hline Location & $\begin{array}{l}\text { Cincinnati, } \\
\text { Ohio }\end{array}$ & $\begin{array}{l}\text { Fargo, } \\
\text { North } \\
\text { Dakota }\end{array}$ & $\begin{array}{l}\text { Miami, } \\
\text { Florida }\end{array}$ & $\begin{array}{l}\text { San } \\
\text { Francisco, } \\
\text { California }\end{array}$ & $\begin{array}{l}\text { Phoenix, } \\
\text { Arizona }\end{array}$ \\
\hline latitude & 39.1 & 46.93 & 25.82 & 37.62 & 33.44 \\
\hline Longitude & 81.44 & 96.81 & 80.3 & 122.4 & 111.99 \\
\hline elevation & 1237 & 899 & 30 & 20 & 1106 \\
\hline
\end{tabular}


R. Talib et al. /Advances in Science, Technology and Engineering Systems Journal Vol. 5, No. 4, 47-53 (2020)

\begin{tabular}{|l|l|l|l|l|l|}
\hline $\begin{array}{l}\text { Heating } \\
\mathrm{DB}\left(\mathrm{F}^{\circ}\right)\end{array}$ & 8.1 & -19.3 & 47.6 & 39.1 & 38.7 \\
\hline $\begin{array}{l}\text { Cooling } \\
\mathrm{DB}\left(\mathrm{F}^{\circ}\right)\end{array}$ & 92.8 & 90.7 & 91.8 & 82.8 & 110.3 \\
\hline Enthalpy & 88.1 & 84.5 & 90 & 74.2 & 106.4 \\
\hline HDD & 4744 & 8729 & 126 & 2689 & 923 \\
\hline CDD & 1155 & 555 & 4537 & 144 & 4626 \\
\hline
\end{tabular}

\subsection{Outside-Air Condition Calculation}

Calculate the outside air temperature and humidity ratio after passing the energy recovery system based on the efficiency of the specific system. The formula used was a derivation based on the efficiency formula provided by ASHRAE Standard 90.1-2016.

$$
\begin{aligned}
T_{o}^{\prime} & =-\eta_{s} *\left(\frac{\dot{m}_{e a}}{\dot{m}_{o a}}\right) *\left(T_{o}-T_{r}\right)+T_{o} \\
W_{o}^{\prime} & =-\eta *\left(\frac{\dot{m}_{e a}}{\dot{m}_{o a}}\right) *\left(W_{o}-W_{r}\right)+W_{o}
\end{aligned}
$$

\subsection{Mixed-Air Condition Calculation}

Calculate the mixed air temperatures between the outside air stream and return air stream. In this energy model, the mixed air is used as the control point for the energy recovery system. For two different cases, (1) with energy recovery and (2) without energy recovery, the required outdoor air fraction to meet the supply air temperature is calculated.

$$
\begin{gathered}
\lambda_{\text {req }}=\frac{T_{s}-T_{r}}{T_{o}^{\prime}-T_{r}} \\
\lambda=\frac{\dot{m}_{o a}}{\dot{m}_{\text {total }}}
\end{gathered}
$$

For both cases, the mixed air temperature and humidity ratio is calculated with the subsequent outside air ratio.

$$
\begin{gathered}
T_{m}=\lambda_{\text {req }} * T_{o}^{\prime}+(1-\lambda) T_{r} \\
W_{m}=\lambda_{\text {req }} * W_{o}^{\prime}+(1-\lambda) W_{r}
\end{gathered}
$$

The difference between the supply air temperature and the mixed air temperature with energy recovery is calculated. Next, the difference between the supply air temperature and the mixed air temperature without energy recovery is calculated. After evaluating the two results, the energy recovery system is signaled to run or not to run [20]. If the energy recovery system was seen to remove or add too much heat, the energy recovery system would be signaled to modulate in order to meet supply air conditions. The supply air temperature is calculated based on a conditional equation, where in full cooling the supply air temperature is $55^{\circ} \mathrm{F}$, and in full heating the supply air temperature is $65^{\circ} \mathrm{F}$. Between the two temperatures, the supply air varies linearly with a slope of $0.5^{\circ} \mathrm{F}$. The formula can be seen in Eq. 8 .

$$
\begin{gathered}
T_{s}=55+0.5\left(65-T_{o a}\right) \\
\text { Lower limit }=55^{\circ} \mathrm{F} \\
\text { Upper limit }=65^{\circ} \mathrm{F}
\end{gathered}
$$

\subsection{Load Calculation}

The load associated with cooling and heating the air on a system level is then calculated for each temperature bin using the following equations.

$$
\begin{gathered}
q_{s}=\dot{m}_{\text {total }} * C_{p} * \Delta t \\
q_{l}=\dot{m}_{\text {total }} * h_{g} *\left(W_{m}-W_{s}\right) \\
q_{t}=\dot{m}_{\text {total }} * \Delta h=q_{s}+q_{l}
\end{gathered}
$$

To find the annual load energy, the load is multiplied by the temperature hourly bin for the occupied schedule in the specific weather file.

\subsection{Energy Consumption Calculation}

In order to calculate the building energy consumption, further assumptions were made about the systems within the building [21]. The building is equipped with an air-cooled chiller, with the efficiency varying as a function of the outside air temperature, between $1.2 \mathrm{kw} /$ ton and $1.0 \mathrm{kw} /$ ton [22]. A natural gas, noncondensing boiler with a COP of 0.85 , meets the building's heating demand. In order to get comparative results for the whole building's energy consumption, eQuest was used to determine the zone level heating requirements for each temperature bin. The building was modeled in each tested city using ASHRAE Standard 90.1-2016 minimum values.

Mentioned in the 'Energy Recovery Systems' section are listed parasitic losses associated with implementing energy recovery systems. For the purpose of this study, these losses are assumed to be limited to the additional fan energy required to overcome the additional pressure drop over the energy recovery system. To calculate the fan energy associated with the air handling unit, it was assumed that the building level static pressure drop is 7 in.w.g. The additional static pressure added to this assumption by the energy recovery system is given in Table 1 . The efficiency of the fan is given by the minimum ASHRAE 90.1-2016 value.

$$
\text { Fan Break Horse Power }=\frac{\left(C F M_{\text {total }} * \Delta p\right)}{6356 * \eta_{\text {fan }}}
$$

\section{Results}

For each location, four energy recovery systems were compared to the baseline case with no energy recovery system. The data is broken down by cooling, heating, and fan energy. The total system energy consumed is the summation of the energies. Note, that only energy within the variable air volume system is considered; lighting, plug loads, space equipment, etc. are not being accounted for in the total energy consumption calculation.

In Cincinnati, OH, it was found that as the efficiency of the energy recovery system increases, the total energy consumption decreases. With no energy recovery the total energy consumed by the system was 949,947 kbtu/year. With the coil loop, heat pipe, sensible wheel, and total energy wheel, the total energy consumption was $855,458 \mathrm{kbtu} / \mathrm{year}$; $834,800 \mathrm{kbtu} / \mathrm{year}$; 794,719 $\mathrm{kbtu} / \mathrm{year}$; and $784,438 \mathrm{kbtu} / \mathrm{year}$ respectively. The energy consumed by the fan increases marginally as the static pressure over the recovery system increases, but not enough to outweigh the energy savings. 


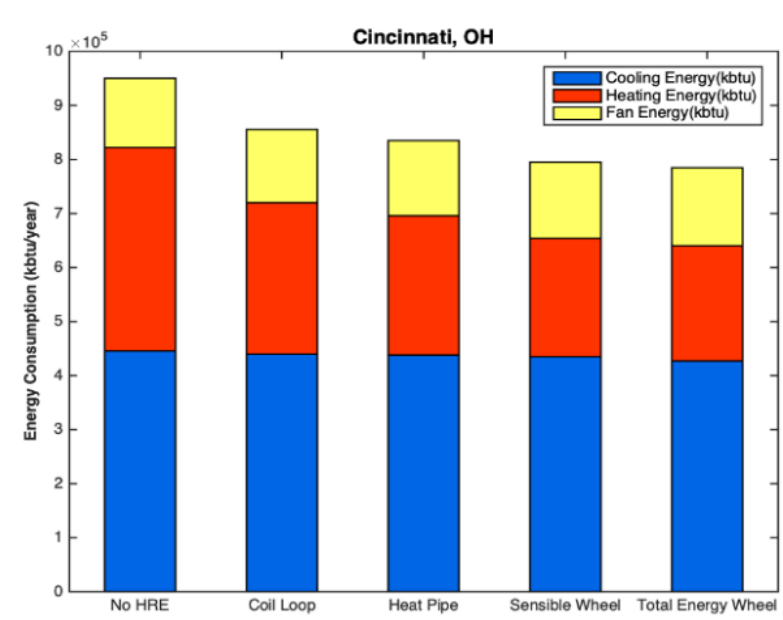

Figure 3: System energy consumption for various energy recovery systems; Cincinnati, $\mathrm{OH}$.

When analysing the differences between energy recovery systems in Fargo, ND, the total energy consumption is noticeably reduced as the efficiency of the recovery system increases. The base case with no recovery system consumed $1,180,362 \mathrm{kbtu} / \mathrm{year}$. Implementing a coil loop, heat pipe, sensible wheel, and total energy wheel yielded energy consumptions of $978,127 \mathrm{kbtu} / \mathrm{year}$, 930,013 kbtu/year, 833,789 kbtu/year and 827,387 kbtu/year respectively. Comparing the sensible energy wheel and the total energy wheel, the sensible wheel saves $29.36 \%$ compared to the baseline, and the total energy wheel saves $29.90 \%$, a very minute difference. Further analysing the breakdown of the total energy consumption, the required cooling energy decreases as the efficiency increases, with the noticeable difference of the total energy wheel. Cooling energy for the total energy wheel was reduced by $1.04 \%$ compared to the baseline, whereas the sensible wheel reduced cooling energy by at $2.33 \%$. When reviewing the energy model, the higher consumption in cooling energy seen in the total energy wheel compared to the sensible wheel can be attributed to the control sequences using dry bulb temperature. Because the system is being controlled by dry bulb temperature, additional moisture is transferred into the mixed air which now must be removed through mechanical cooling. Due to Fargo's cold temperature, the large amount of heating energy saved by the total energy wheel outweighs the added fan and cooling energy, resulting in the most energy saved.

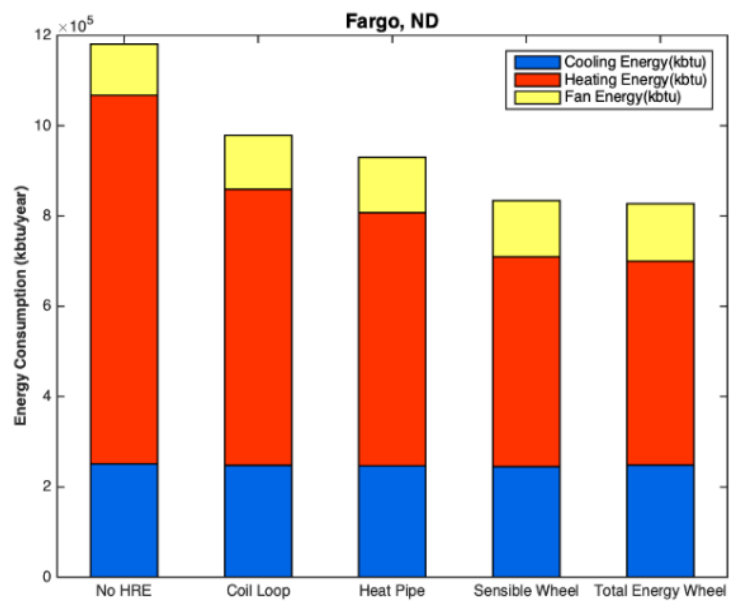

Figure 4: System energy consumption for various energy recovery systems; Fargo, ND.
In Phoenix, AZ, the baseline with no recovery system consumed 844,231 kbtu/year. The coil loop, heat pipe, sensible wheel, and total energy wheel consumed 824,696 kbtu/year, $822,316 \mathrm{kbtu} /$ year, 811,621 kbtu/year, 843,835 kbtu/year respectively. The system with the largest reduction in energy is the sensible wheel, producing a savings of $3.86 \%$ compared to a reduction of only $0.05 \%$ by the total energy wheel. The sensible wheel reduced cooling energy by $6.60 \%$ while the energy wheel reduced it by only $2.35 \%$. Similar to Fargo, the lower reduction in cooling energy of the total energy wheel can be attributed to the programmed system being controlled by dry bulb temperature.

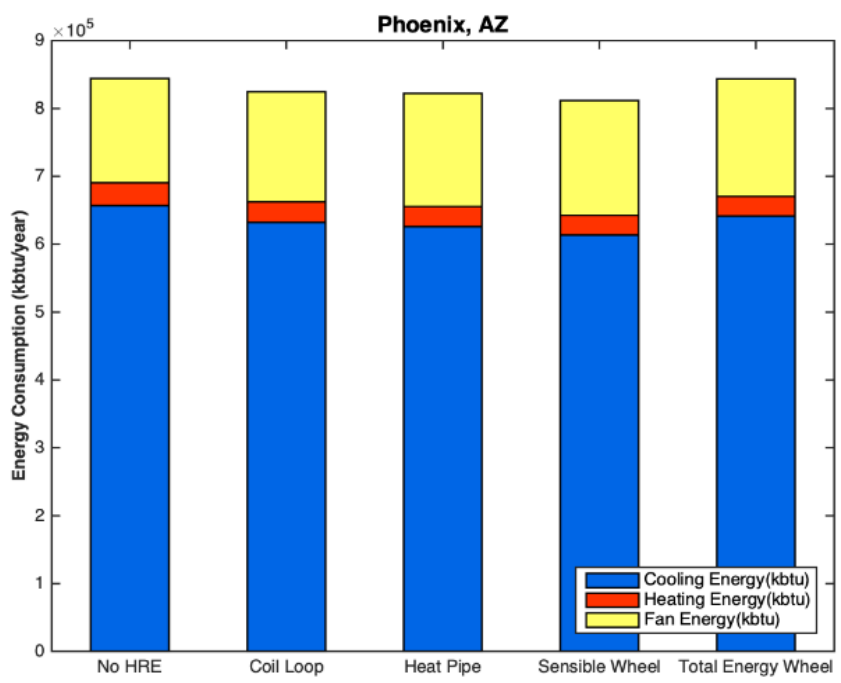

Figure 5: System energy consumption for various energy recovery systems; Phoenix, AZ.

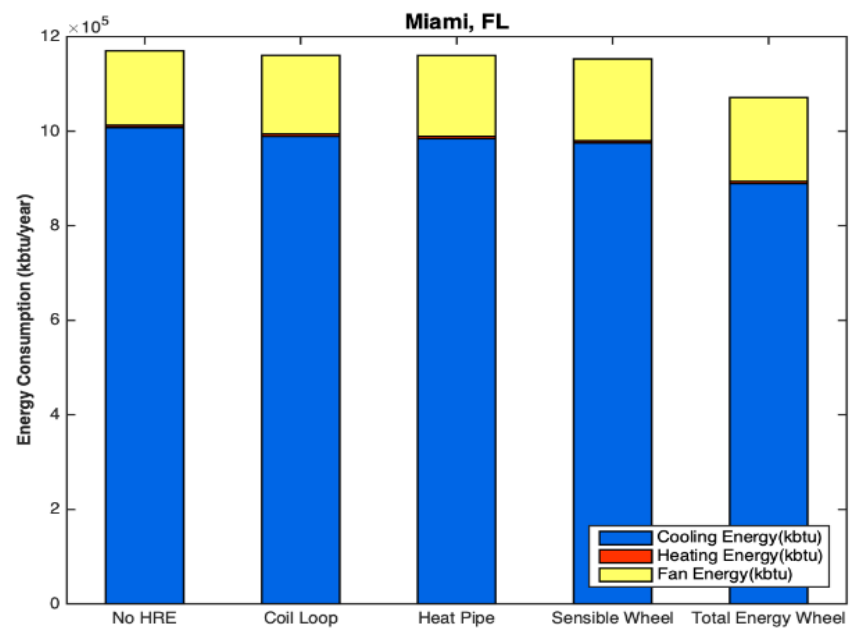

Figure 6: System energy consumption for various energy recovery systems; Miami, FL

In Miami, FL all systems show a savings in total energy consumption as the efficiency of the recovery systems increased. The baseline case consumed 1,170,108 kbtu/year, whereas the coil loop, heat pipe, sensible wheel, and total energy wheel consumed $1,160,188 \mathrm{kbtu} /$ year, 1,159,955 kbtu/year, 1,152,901 kbtu/year, and 1,071,395 kbtu/year respectively. The sensible recovery technologies, the coil loop, heat pipe, and sensible wheel yielded savings from the baseline of $0.85 \%, 0.87 \%$, and $1.47 \%$ respectively. Total energy wheels, which transfer both sensible and latent energy, reduces total energy consumption by $8.44 \%$, almost a $7 \%$ gain in efficiency compared to the sensible wheel. The 
sensible wheel and total energy wheel have the same heating consumption, $4,774 \mathrm{kbtu} / \mathrm{year}$, because the heating load in the air handling unit is entirely accomplished through energy recovery. This remaining heat is added at the zone level.

In San Francisco, CA the energy consumption for all energy recovery systems increase compared to the baseline. The baseline model with no recovery system consumed 453,100 kbtu/year, and the coil loop, heat pipe, sensible wheel, and total energy wheel consumed 453,395 kbtu/year, 456,159 kbtu/year, 457,069 $\mathrm{kbtu} /$ year, 462,986 kbtu/year respectively. For sensible recovery systems (coil loop, heat pipe, and sensible wheel), the heating and cooling energy is minimally reduced. The increase in parasitic energy used by the fan outweighs the savings from heating and cooling. In contrast the total energy wheels usage of cooling energy is greater than that of the baseline due to the control sequences based on dry bulb temperature. The implementation of the total energy wheel increased energy consumption by $2.18 \%$ compared to the baseline.

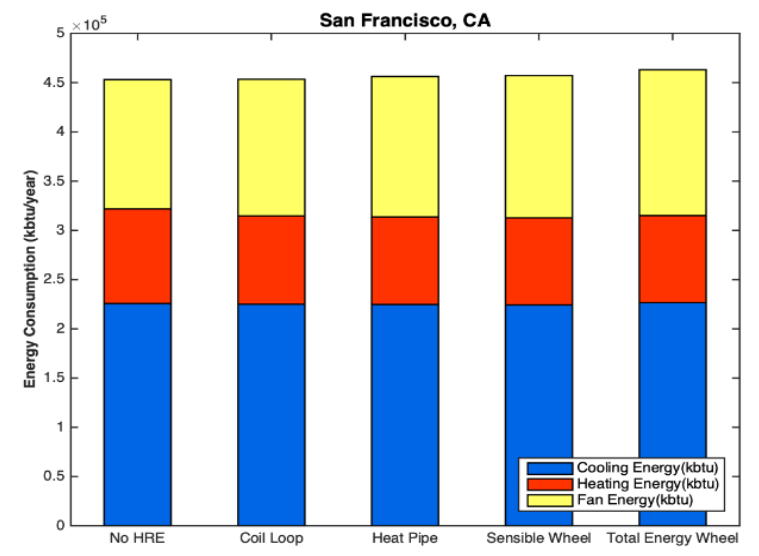

Figure 7: System energy consumption for various energy recovery systems; San Francisco, CA.

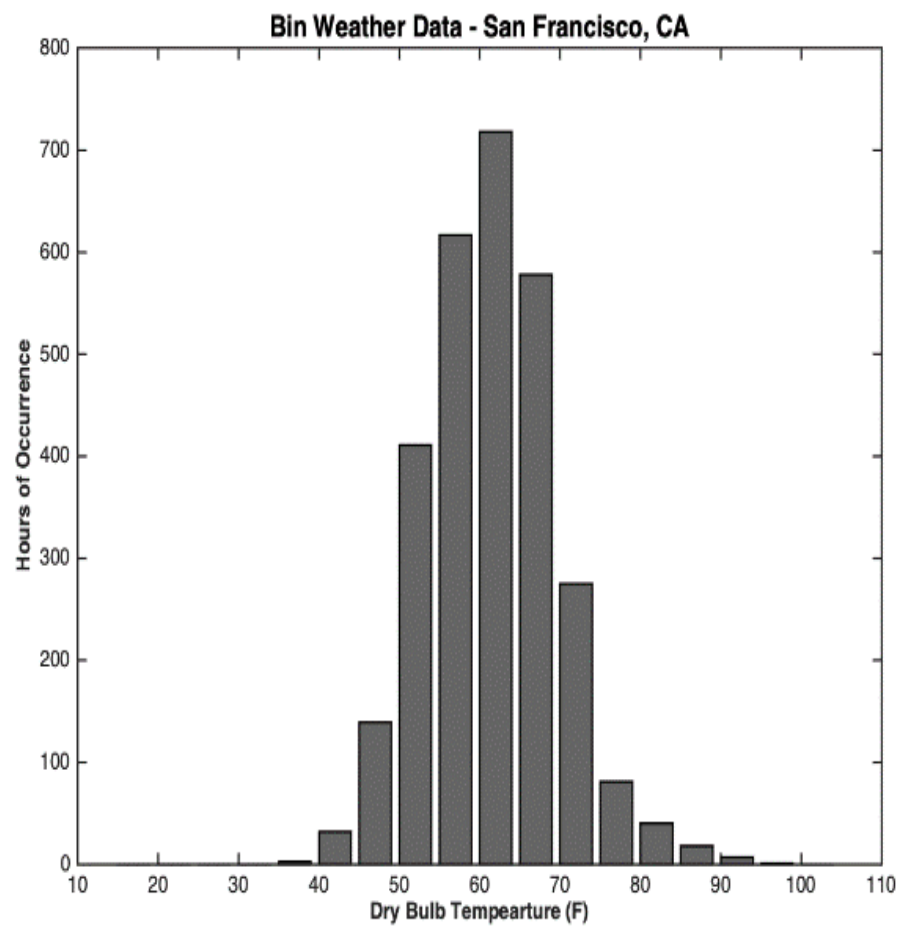

Figure 8: Hourly temperature occurrence; San Francisco, CA.
San Francisco has a noticeably mid climate, with $70 \%$ of the hours in a year falling within the $52 \mathrm{~F}-62 \mathrm{~F}$ range. This climate requires little to no air conditioning. When looking at the energy model, it became clear that for most temperature bins, the control sequencing was able to control the dampers in order to meet the supply air requirements without mechanical conditioning.

\section{Conclusion and Discussion}

Air to air energy recovery devices are reliable and effective methods that are implemented to reduce the total auxiliary energy use as well as improving the indoor air quality through higher ventilation rates. Systems that are equipped with energy recovery devices were proven to be more effective than the ones who don't. With the availability of several types of energy recovery devices choosing the most suitable one for the application is crucial to achieve comfortable and cost-effective buildings [23].

In this paper, four types of energy recovery systems were studied in five different climate zones, and their system's energy consumption were analysed. The energy recovery systems are:

\section{Coil loop,}

2. Heat pipe,

3. Sensible wheel,

4. Total energy wheel.

The locations are Cincinnati, OH, Fargo, ND, Miami, FL, San Francisco California, and Phoenix Arizona. Figure 9 illustrates the reduction in energy for each system in each location.

From the results of this analysis, an underlying takeaway is that energy recovery systems produce different results depending on the conditions and locations in which they operate. The largest savings in energy consumption occurs in climates that are heating dominated, as seen in the results from the simulation in Fargo, ND (ASHRAE Climate Zone 7). It is also notable that in areas with dry climates and high sensible heat ratios, the use of a system that transfers both sensible and latent energy must be studied with care in regard to the control sequencing.

Moreover, in this study the sole control point of the system was based on dry bulb temperature, limiting the optimization of the systems. Expanding the possible control sequences to include the air's humidity ratio or enthalpy will create a more perspective aid in selecting energy recovery systems and control strategies. This study is the basis for the development of a design tool that will pair with known energy simulation software such as eQuest to provide project specific energy reduction values based on various energy recovery systems.

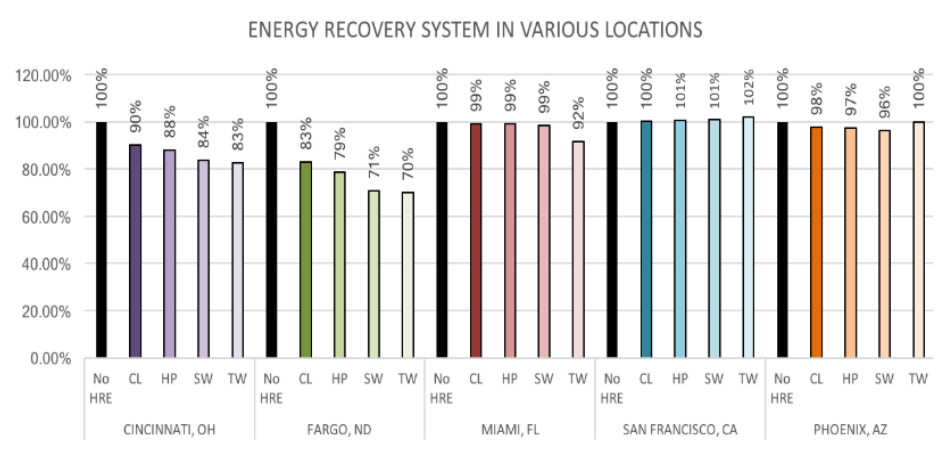

Figure 9: Comparison of all energy recovery systems in all tested locations values are presented as a percentage of the baseline with no energy recovery system. 


\section{Conflict of Interest}

The authors declare no conflict of interest.

\section{References}

[1] U.S. Energy Information Administration, "How Much Energy is Consumed in U.S. Residential and Commercial Buildings?", 3 May, 2018. Available: https://www.eia.gov/tools/faqs/faq.php?id=86\&t=1

[2] U.S. Department of Energy, "Chapter 5: An Assessment of Energy Technologies and Research Opportunities", September, 2015. Available: https://www.energy.gov/sites/prod/files/2017/03/f34/qtr-2015-chapter5.pdf

[3] International Well Building Institute, "The WELL Building Standard", 20 October, 2014.

[4] American Society of Heating Refrigerating and Air-conditioning Engineers, Inc. (ASHRAE), Standard 62.1-2016, "Ventilation for acceptable Indoor Air Quality", 2016.

[5] R. Talib, N. Nassif, M. Arida, \& T. Abu-Lebdeh, "Chilled water VAV system optimization and modeling using artificial neural networks", American Journal of Engineering and Applied Sciences, 11 (4), 1188-1198, 2018. doi:10.3844/ajeassp.2018.1188.1198

[6] W. Wu, X. Li, T. You, \& Ohio Library and Information Network, "Absorption heating technologies: Efficient heating, heat recovery and renewable energy", Singapore: Springer, 2018. doi:10.1007/978-981-150470-9

[7] Dieckmann, John, Kurt W. Roth, and James Brodrick. "Air-to-air energy recovery heat exchangers." ASHRAE Journal 45(8), 57, 2003.

[8] Sauer Jr, H. J., and R. H. Howell. "Promise and potential of air-to-air energy recovery systems." International Journal of Refrigeration 4.4: 182-194. 1981.

[9] American Society of Heating Refrigerating and Air-conditioning Engineers, Inc. (ASHRAE), Standard 90.1-2016, Energy Standard for Buildings Except Low-Rise Residential Buildings, Atlanta, GA, USA, 2016.

[10] Nasr, Mohammad Rafati, et al. "A review of frosting in air-to-air energy exchangers." Renewable and Sustainable Energy Reviews 30: 538-554, 2014.

[11] N.T. Madineedi, J.M. Harrell, \& J.A. Mathias, "Redesigning the HVAC system of a university laboratory building", ASHRAE Transactions, 123(2), 217, 2017.

[12] Besant, Robert W., and Carey J. Simonson. Air-to-air energy recovery. ASHRAE journal 42(5), 31-43, 2000.

[13] M. Kanaan, "CFD optimization of return air ratio and use of upper room UVGI in combined HVAC and heat recovery system", AMSTERDAM: Elsevier Ltd, 2019. doi:10.1016/j.csite.2019.100535.

[14] Trane Engineers Newsletter Live - Ronnie Moffitt, Dennis Stanke, John Murphy, Jeanne Harshaw, Air-to-Air Energy Recovery, 10 August 2012.

[15] Freund, Sebastian, "Simulation of Air-to-Air Energy Recovery Systems for HVAC Energy Conservation in an Animal Housing Facility," Master of Science thesis, Solar Energy Laboratory University of Wisconsin-Madison, 2003.

[16] eQuest. Quick Energy Simulation Tool, eQuest Version 3.65. Available: http://doe2.com/equest/

[17] M.N. Hydeman, P. Sreedharan, and S. Blanc, "Development and Testing of a Reformulated Regression-Based Electric Chiller Model, ASHRAE Transactions 105(2), 1118-27, 2012.

[18] National Climatic Data Center - National Oceanic and Atmospheric Administration: Cincinnati, Ohio; Fargo North Dakota; Miami, Florida; San Francisco, California; Phoenix, Arizona. Available: http://www.ncdc.noaa.gov

[19] Ashrae handbook, "Fundamentals by American Society of Heating, Refrigerating and Air-Conditioning Engineers", 2013. eBook: Full Text Online, TH7011.A4222 2013eb

[20] N. Nassif, S. Kajl, and R. Sabourin, "Optimization of HVAC Control System Strategy Using Two-Objective Genetic Algorithm", HVAC\&R Research. 11(3), 459-486, 2005. DOI: 10.1080/10789669.2005.10391148

[21] W. Wu, H.M. Skye, H. M., \& P.A. Domanski, "Selecting HVAC systems to achieve comfortable and cost-effective residential net-zero energy buildings. Applied Energy, 212, 577-591, 2018. doi:10.1016/j.apenergy.2017.12.046.

[22] Ali, M. Tauha - MathWorks MATLAB, SI Psychrometric Chart, 2015. Available: https://www.mathworks.com/matlabcentral/fileexchange/49154si-psychrometric-chart
[23] X. Pei, "Application of exhaust heat recovery in energy saving of HVAC", IOP Conference Series: Earth and Environmental Science, 295, 52009, 2019. doi:10.1088/1755-1315/295/5/052009

\section{Nomenclature}

\begin{tabular}{|c|c|}
\hline$E R E$ & energy recovery effectiveness \\
\hline$\dot{m}_{o a}$ & mass flow rate - outside air $(\mathrm{lb} / \mathrm{hr})$ \\
\hline$\dot{m}_{e a}$ & mass flow rate - exhaust air $(\mathrm{lb} / \mathrm{hr})$ \\
\hline$\dot{m}_{\text {total }}$ & mass flow rate - total system air $(\mathrm{lb} / \mathrm{hr})$ \\
\hline$C F M_{o a}$ & outside air volumetric flow rate $\left(\mathrm{ft}^{3} / \mathrm{min}\right)$ \\
\hline$C F M_{e a}$ & exhaust air volumetric flow rate $\left(\mathrm{ft}^{3} / \mathrm{min}\right)$ \\
\hline$C F M_{\text {total }}$ & system total air volumetric flow rate $\left(\mathrm{ft}^{3} / \mathrm{min}\right)$ \\
\hline$C D D$ & Cooling degree days \\
\hline$H D D$ & Heating degree days \\
\hline$D B$ & Dry bulb temperature $\left(\mathrm{F}^{\circ}\right)$ \\
\hline$h_{o}$ & outside air enthalpy (btu/lb) \\
\hline$h_{o \prime}$ & $\begin{array}{l}\text { outside air enthalpy after energy recovery } \\
\text { equipment (btu/lb) }\end{array}$ \\
\hline$h_{e a}$ & exhaust air enthalpy (btu/lb) \\
\hline$\eta_{s}$ & sensible efficiency of recovery system (\%) \\
\hline$T_{o}$ & outside air temperature $\left({ }^{\circ} \mathrm{F}\right)$ \\
\hline$T_{o}^{\prime}$ & $\begin{array}{l}\text { outside air temperature after energy recovery } \\
\text { system }\left({ }^{\circ} \mathrm{F}\right)\end{array}$ \\
\hline$T_{r}$ & return air temperature $\left({ }^{\circ} \mathrm{F}\right)$ \\
\hline$h_{g}$ & latent heat of vaporization (btu/lb) \\
\hline$\eta_{l}$ & latent efficiency of energy recovery system (\%) \\
\hline$W_{o}$ & outside air humidity ratio (lb/lb) \\
\hline$W_{o}^{\prime}$ & $\begin{array}{l}\text { outside air humidity ratio after energy recovery } \\
\text { system (lb/lb) }\end{array}$ \\
\hline$W_{r}$ & return air humidity ratio $(\mathrm{lb} / \mathrm{lb})$ \\
\hline$\lambda_{\text {req }}$ & outside air ratio to meet $\mathrm{T}_{\mathrm{s}}(\%)$ \\
\hline$\lambda$ & Outside air ratio $(\%)$ \\
\hline$T_{m}$ & mixed air temperature $\left({ }^{\circ} \mathrm{F}\right)$ \\
\hline$W_{m}$ & mixed air humidity ratio (lb/lb) \\
\hline$q_{s}$ & sensible load (btu/hr) \\
\hline$q_{l}$ & latent load (btu/hr) \\
\hline$q_{t}$ & total load (btu/hr) \\
\hline$\Delta p$ & differential pressure (in w.g.) \\
\hline$\eta_{\text {fan }}$ & fan efficiency $(\%)$ \\
\hline OSCF & outside air correction factor \\
\hline
\end{tabular}

